\title{
The Dynamic Impacting Study of Competitive Strategies to Import Retail E-Commerce Sellers
}

Xuanxuan Zhang, College of Economics and Business Administration, Chongqing University, Chongqing, China

\begin{abstract}
The authors investigated several import retail e-commerce sellers through questionnaires and selected several types of variables based on Porter's competitive strategy theory. Then the authors used the panel data to empirically verify theoretical consumptions based on samples got by Python method from Jingdong Global Purchases and Tmall International, the top two e-commerce platforms in China. Results validated the three major competitive strategies that could enhance the competitive advantages to import retail e-commerce sellers. As it was not applied to all platforms and commodities, sellers should make different strategies through different platforms and commodities. This article has theoretical significance that filled in the gaps on import retail e-commerce sellers' competition. It also has certain practical significance by providing references for sellers on how to improve their competitive advantages, promote healthy competition and development of the import retail e-commerce, even to facilitate the structure adjustment of consumption and foreign trade in China.
\end{abstract}

\section{KEYWORDS}

Competitive Strategy, Cost Leadership, Imported Retail E-Commerce, Panel Data, Porter, Product Optimization, Reputation Priority

\section{INTRODUCTION}

Nowadays, import retail e-commerce ${ }^{1}$ would be the hottest topic in China's e-commerce industry. There were four main reasons for this. The first was the changing of China's foreign trade way. The traditional way of cross-border trade grew sluggishly after the global financial crisis in 2008 while cross-border e-commerce was rising rapidly. Traditional trade volume fell $0.9 \%$ in the whole year of 2016, and cross-border e-commerce trading reached 6.3 trillion yuan with the growth rate of $23.5 \%$. Import retail e-commerce trading scale up to 305.47 billion yuan with the growth rate of $47.36 \%$ (iResearch, 2017). The second was the changing of economic growth momentum. In macro aspect, the contribution rate of consumption to economic growth reached 64.6\% in 2016(National Bureau of Statistics of China, 2017). In micro aspect, the consuming way has changed from offline to online and from domestic consuming to cross-border consuming as the generation after 80 s became the main subject of domestic consuming market (Guo, Wang and Chen, 2015; Mao \& Yang, 2017). The third factor was that imported retail e-commerce has two advantages compared to traditional physical store 
sales channels: the reduction of fixed cost (Wu, 2007; Lu \& Feng, 2009) and the lower tax rate ${ }^{2}$. The forth was that a number of documents have been issued to promote and standardize the development of import retail e-commerce from 2014 ( $\mathrm{Li} \& \mathrm{Ma}, 2016$ ). With the rising of this business, it was essential to analyze import retail e-commerce carefully and deeply.

\section{LITERATURE REVIEW}

At present, there were few researches directly related to our article, the authors would summarize contributions into three aspects: research topics, research theories and research methods.

In terms of research topics, the previous researches to import retail mainly focused on macroscopic perspective. Saipe (2013) used cross-border e-commerce sellers in United States and Canada as research samples and found that cross-border and domestic logistics costs have a significant impact on their profits. At the same time, the free shipping mode can increase the volume of cross-border e-commerce transactions in US and Canada. Hsiao (2017) has found that a satisfactory CBLS ${ }^{3}$ provider could promote cross-border e-commerce transaction volume. Liu (2015) proposed certain research proposals on the development of cross-border e-commerce and promotion of trade cooperation relations based on relevant bilateral trade agreements between China and Russia.

In terms of research theory, there were many researches on the competition strategies among enterprises, but the most representative one was Porter's (2001) competitive strategy theory, which summarized three basic strategies to determine strategic advantages on Internet enterprises: product optimization, cost leadership and reputation priority. Many scholars (Ge \& Zhang, 2013; Rodder \& Reucher, 2012) verified factors that affect the Internet companies' competitive strategies based on Porter's theory. Product optimization strategy meant that sellers attracted consumers through the different categories of commodities. Zheng, Wang, Liu, Ni and Wu (2014) proved that product innovation has a positive influence on promoting sales volume of electric commerce enterprise by collecting 309 samples on Tmall. Xue \& Guo (2012) proposed that the sale of virtual goods or small and low-cost goods would be beneficial to e-commerce sellers to enhance their competitive advantage. However, there was such strict supervision over import retail e-commerce products. Firstly, virtual goods were not allowed to sell. Secondly, commodities sold should be in the "positive list"4. In addition, according to statistics from AliResearch (2016), the sales volume of three main categories of domestic import retail e-commerce products which were mother and infant supplies, cosmetics and health care products and these items reached $72 \%$ of the total sales volume of domestic import retail e-commerce. Cost leadership strategy meant to provide low price commodities with low unit cost to attract consumers. Sun, Zhang and Jiang (2017) proved that e-commerce could lower the cost by increasing searching efficiency, and found that equilibrium price would be different by different searching efficiency. Gomez, Martens and Turlea (2014) confirmed that the cross-border online transaction costs were much lower than the costs of offline transactions due to the decrease in the tax rate, rent, and searching costs. But the logistics costs and waiting costs cannot be ignored (Mudambi \& Schuff, 2010; Cheung, Luo and Sia, 2009), especially the logistics way of import retail e-commerce 5 . If it was direct mail import, the delivery of goods was completed by CBLS (Hsiao, 2017) and it made higher waiting cost as involved buyers and sellers from different countries (Chen, Hsu and Chang, 2015). A high-quality CBLS could not only enable buyers and sellers to complete cross-border e-commerce transactions, but also could enhance the customer's stickness to cross-border e-commerce sellers. Xue \& Guo (2012); Li, Wu and Xu (2007) proved that logistics advantages have a significant effect on e-commerce sellers' competitive advantage. Wang \& Du (2016) directly advised that import retail e-commerce sellers could enhance their business performance by establishing an effective supply chain logistics system. Therefore, it was important to analyze different waiting and logistics cost caused by different price of the goods, freight and logistics way to reduce the cost for sellers. However, few researches have been made in China at present. Reputation priority strategy was to make comprehensive management of a company's reputation at strategic level, and to convey 
company's value, product and business mode timely and accurately. It was difficult to experience online shopping caused by different waiting and logistics costs which were brought about by different logistics ways (Mudambi \& Schuff, 2010) before order. In this case, other consumers' online reviews have become necessary resources for them to reference (Liu \& Xu, 2014). The reputation priority was online word of mouth in the Internet environment (Arndt, 1967), which were other consumers' online comments to sellers' commodities and services. Liu \& Xu (2014) has done an empirical test through the Tobit mode to 2372 users' reviews based on the samples from Dazhong, analyzing the effectiveness of information's quality. Sparks, So and Bradley (2016), Zhang \& Squez(2014) analyzed the psychological impact of online reviews on consumers' online booking of hotels and how hotels manage consumers' negative evaluation. Of course, the effectiveness of online word of mouth was most widely used in the field of online shopping. Many domestic and foreign scholars have confirmed the impact of online word of mouth to volume of online sales by analyzing samples of Amazon and other e-commerce platforms (Mudambi \& Schuff, 2010; Sohail \& Siddiqui, 2016; Vinodhini \& Chandrasekaran, 2016). Most researches were static samples which based on observation of a time point, lack of an observation on period of time. Therefore, based on the different experience of import retail e-commerce consumers (Wang \& Du, 2016) and the unique logistics characteristics of this industry, the three strategies proposed by Porter were also applied to the competition among import retail e-commerce sellers. In the aspect of research methods, panel data ${ }^{6}$ was widely used by domestic and foreign scholars as it improved the quality of results by extending the traditional time series regression to the two dimensions. There were so many research results so that the authors would not discuss in detail one by one.

Therefore, the contribution of this paper could be summarized in three aspects. The first one was the object of our study, as there were few researches involved in Chinese import retail e-commerce. The authors focused on the competition among import retail e-commerce sellers, and have done an empirical research to prove conclusions based on samples from the top two of domestic e-commerce platforms. The second one was the theory of our research. Competitive strategies of enterprises were always the hottest topic of management. The authors have done theoretical analysis to the characteristics of import retail e-commerce industry and questionnaire survey to 237 import retail e-commerce sellers based on Porter's competitive strategy theory, and screened out several factors that affect the competitive advantage of import retail e-commerce sellers, analyzing advantages and disadvantages to enhance the competitive advantage of each factor. The third one was our research method. The authors used panel data to do empirical research to competitive strategy of import retail e-commerce sellers through an observation to changes in related factors in 27 weeks. The authors provided several suggestions on how to improve the competitive advantage to import retail e-commerce sellers which have a certain practical significance.

\section{THEORETICAL ANALYSIS AND RESEARCH METHODOLOGY}

\section{Data Sources}

The authors have done questionnaire ${ }^{7}$ to parts of import retail e-commerce enterprises in the first batch of seven pilot cities ${ }^{8}$ through visiting, email and telephone. Enterprises under investigation have been in import retail e-commerce industry for 2 years at least. Most of them have online shops in Tmall International or Jingdong Global Purchase, and have sold three categories of commodities.

The total volume of domestic import retail e-commerce sellers has exceeded one million, so it was perfectly competitive market. But domestic import retail e-commerce platform belonged to the typical oligopoly market. The sales volume of Tmall International, Jingdong Global Purchase and Netease Kaola which represent the third-party residing type platforms, integrated platforms and self-operated platforms ${ }^{9}$ respectively, has reached $55 \%$ of the total sales volume of Chinese import retail e-commerce market in 2016. This article would select 8 commodities in these 3 categories of products respectively both on Jingdong global purchase and Tmall International as samples ${ }^{10}$. The 
authors used Python technology to collect sales data for 24 products ${ }^{11}$ from Tmall International and Jingdong Global Purchase from November 20, 2016 to July 16, 2017. In order to maintain product sales page relatively static as the e-commerce sellers' pages updated very often, the authors set the collection time from 1 o'clock am at every Monday morning. The authors also considered that some stores being closed, some products being took off the shelf during the observation period. After eliminating a series of invalid and abnormal data, a total number of 18,144 samples of 14 sellers from each of the above three categories of goods were collected. The collection period was 27 weeks which was from November 27, 2016 to May 28, 2017.

So the process of data collecting could be summarized as follows. Firstly, the authors collected factors that describe three major competitive strategies through questionnaire survey. Secondly, the authors used Python technology to collect data online at a fixed time point based on factors acquired from questionnaire. Thirdly, the authors sorted the raw data manually, including eliminated the system automatically default credit data and missing variable data items, sorted through online review samples manually and acquired the ratio of negative comments. Fourthly, the authors divided data into two dimensions to do regression: platform dimension and commodity dimensions.

\section{Variable Setting and Theoretical Hypothesis}

Sellers' competitive advantage was often reflected in their total volume and amount of sales $(\mathrm{Li}, \mathrm{Wu}$ and $\mathrm{Xu}, 2007)$. Considering that the total sales volume itself has a certain impact on the total amount of online comments, this article took ratio of the total sales volume to total online comments (Sales/ Judge) to measure the competitive advantage ( $A d v)$ of import retail e-commerce sellers (Qian, Cao and $\mathrm{Li}, 2011$ ). In terms of product optimization strategy, not all commodities were suitable for trading on e-commerce platforms. The choice of imported retail e-commerce sellers to optimize the sale of goods was the premise to enhance their competitive advantage. Therefore, this article considered the product optimization strategy mainly from the following two aspects. The first was the after-sales service, according to the logistics ways of import retail e-commerce sales channel, the return process of direct mail way was very complicated ${ }^{12}$. Most sellers would not allow the return of commodities. According to our observation on 18,144 samples, the percentage of allowed return was only $38.32 \%$. Once the return of commodities was not allowed, it meant that consumers need to bear the implicit cost of accepting unsatisfactory commodities. Therefore, according to the description proposed by Zhai \& Li (2011) that returning policy can enhance consumers' online shopping experience, the authors set dummy variable to describe whether import retail e-commerce sellers allowed consumers to return commodities ${ }^{13}$.

\section{Hypothesis One}

Whether import retail e-commerce sellers allowed consumers to return commodities (Return) was directly proportional to the competitive advantage of sellers ( $A d v)$.

The second was logistics costs and waiting costs, which were the two types of costs that consumers cannot ignore in shopping online. Virtual goods would not be considered in this paper as they were not permitted to sell in the import retail e-commerce channel. Then, the expected arriving days (ETA) which describe the waiting costs had strong relationship with sellers' preparation and delivery of goods. Consumers would buy commodities with a longer expiration period in bulk because multiple purchases would raise consumer's logistics costs and waiting costs.

\section{Hypothesis Two}

Expected arriving days was inversely proportional to the competitive advantage of import retail e-commerce sellers.

\section{Hypothesis Ten-1}

Commodities with a shorter expiration period has stronger negative effect to expected arriving days. 
In terms of cost leadership strategy, Porter pointed out it was not easy to achieve cost leadership strategy because merely depending on low-price competition was not rational. The above-mentioned product optimization strategy actually included cost-leading strategy ${ }^{14}$. Import retail e-commerce sellers can also obtain cost and price advantages from other aspects except logistics costs and waiting costs. The first was the investment of warehouse in bonded area as bonded imported could lower consumers' waiting costs because it has shortened the delivery time. The authors used two dummy variables which were whether sellers exempt postage for consumers (Freight $)^{15}$ and the logistics ways (Way) by sellers ${ }^{16}$ to measure logistics costs and waiting costs respectively.

\section{Hypothesis Three}

Whether sellers exempt postage for consumers was directly proportional to the competitive advantage of sellers.

\section{Hypothesis Four}

The logistics ways by import retail e-commerce sellers was directly proportional to the competitive advantage of sellers.

The authors found that consumers cared the most about the price of commodities but not logistics costs and waiting costs through the survey of questionnaire. Due to the fact that purchasing cost of sellers directly determined the commodities' price (Price), the purchasing channel of sellers would be important. Through the questionnaire, there were three channels for import retail e-commerce sellers to purchase goods, which were directly cooperated with branding parties, cooperated with authorized dealers and swept goods in shopping malls overseas. Sellers directly cooperating with brand parties made the lowest cost but had the highest threshold for them; sellers swept goods in shopping malls overseas made the highest cost but had the lowest threshold, while the cost and the threshold that sellers cooperated with authorized dealers would fall between them. The authors can see that ${ }^{17}$ sellers of mother and infant supplies mostly cooperate with branding business, while sellers of cosmetics mostly cooperated with authorized dealers. As more and more Chinese were buying mother and infant supplies aboard nowadays, sellers could easily got authorization aboard. Price competition is intense, and the pricing is particularly important.

\section{Hypothesis Five}

The price of commodities was inversely proportional to the competitive advantage of import retail e-commerce sellers.

Reputation was undoubtedly a differentiating factor for e-commerce sellers to gain competitive advantage, and it equaled to "currency" online (Xue \& Guo, 2012; Mudambi \& Schuff, 2010). The description of the reputation priority strategy (Reputation) in this paper mainly considered the negative comments' ratio $(N R)^{18}$ (Mudambi \& Schuff, 2010; Yan \& Meng, 2013), and the total volume of replies (Mudambi \& Schuff, 2010).

\section{Hypothesis Six}

The negative comments' ratio was inversely proportional to the competitive advantage of import retail e-commerce sellers.

\section{Hypothesis Seven}

The total volume of replies was positively proportional to the competitive advantage of import retail e-commerce sellers.

Furthermore, the authors considered the interactive influence of reputation priority strategy to other strategies. The most intuitive one was the relationship between the price and the reputation. Zhao, Qiu, Hu and Liu (2017) explored attentions of short-sighted consumers and strategic consumers to the price and the reputation. Wang, Wang and He (2007) analyzed the effectiveness to purchase 
intention caused by the quality and price of commodities. Therefore, the authors took the variable (NR*Price) between the negative comments' ratio and the price of commodities as an interaction term in order to analyze the relationship between the price and the reputation. Theoretically speaking, the negative effect to competitive advantage caused by the price of commodities would be weakened if sellers have a good reputation. On the contrary, the negative comments' ratio will strengthen this effect.

\section{Hypothesis Eight}

The negative comments' ratio would enhance the negative effect of the price of commodities to the competitive advantage of import retail e-commerce sellers.

In addition, the rating display of sellers (Rating) included the consistence of the description to the product (Description), the service of the seller (Service) and the speed of the delivery (Speed). The authors used multiple-choice questions to surveyed factors of reputation priority strategy. A few results of the survey can be drawn ${ }^{19}$.In terms of online reviews, the rating of negative comments was considered to be the most important factors, and the number of sellers believe that the total number of reviews, the negative comments' ratio, and total number of replies were important exceeded $75 \%$. In terms of online ratings, the number of sellers exceeded $70 \%$ that believe all three ratings to sellers were important.

\section{Hypothesis Nine}

The rating to sellers (Rating) was positively proportional to the competitive advantage of import retail e-commerce sellers.

Online review was crucial due to the lack of consumers' understanding to cross-border shopping logistics ways and quality of commodities (Sparks, So and Bradley, 2016; Zhang \& Squez, 2014). In addition, domestic consumers were lack of confidence to the quality of domestic products especially in mother and infant supplies.

\section{Hypothesis Ten-2}

Mother and infant supplies played a stronger role in the reputation priority strategy.

In addition, different platforms would definitely bring about different shopping experience for consumers, especially in the aspect of reputational priority strategies. Tmall International (iResearch, 2017) which was based on Alibaba's global strategy was the largest e-commerce platform in China and had a strict threshold for e-commerce sellers to enter. Jingdong Global Purchase was a comprehensive e-commerce platform with a combination of self-operations and third-party residing operations. The authors only considered the competition among import retail e-commerce sellers, and would not consider the platform operation in this paper.

\section{Hypothesis Ten-3}

Tmall International platform played a stronger role in reputation priority strategy.

Finally, the analytical framework diagram of this study was shown in Figure 1.

\section{Descriptive Statistics and Correlation Test of Variables}

Before the regression, the authors have done descriptive statistics and correlation tests to variables. Results of descriptive statistics of variables ${ }^{20}$ showed that the expected arriving days of cosmetics was longer than other two commodities as it has a longer expiration period, and sellers would take direct mail logistics way to delivery it in order to take limited warehouses space in bonded area to other commodities with shorter expiration period. This was mutual corroboration with the high rating to the speed of the delivery of mother and infant supplies. In addition, the mean value of whether import retail e-commerce sellers allowed consumers to return commodities of mother and infant supplies was lower than other two commodities, which stated that mother and infant supplies' sellers 


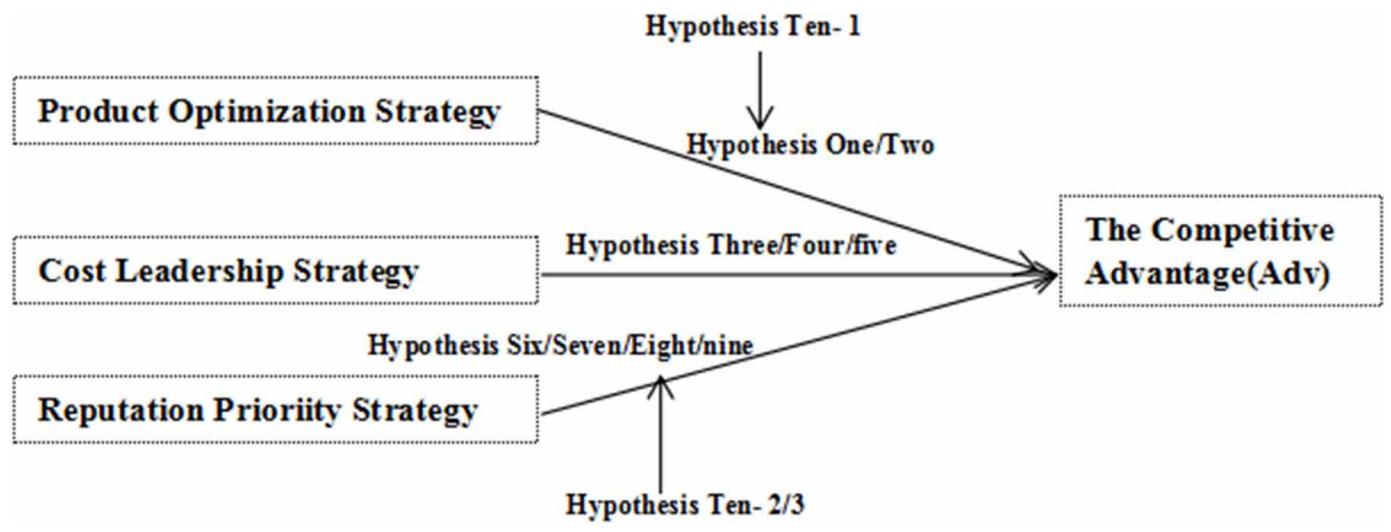

would not allow consumers to return commodities. The results of correlation test of variables showed that ${ }^{21}$, firstly, the correlation coefficient between the expected arriving days and the logistics ways by import retail e-commerce sellers was so high $^{22}$. Secondly, the correlation coefficient among the rating to consistence of the description to the product, the rating to the service of the seller and the rating to the speed of the delivery was so high. Therefore, the authors chose the expected arriving days and the rating to the speed of the delivery to do empirical research, and chose the logistics ways by import retail e-commerce sellers and the rating to consistence of the description to the product as variables to do robustness test.

\section{RESEARCH MODEL}

The authors used the lagged variables of endogenous variables as instrumental variables to solve endogenous problem would be caused by bidirectional causality among variables. However, the research issued in this paper had the following characteristics. First, sellers' competitive strategies would all be endogenous. Consumers made purchasing decision after they saw the information on the sellers' website. So the impact would not be reflected in the current period. Second, websites' updating speed was very often so that the lag period should not be too long. The authors used one lag-phase data for all explanatory variables to analyze the problem. In addition, in order to make the dimension of data roughly consistent, the authors have also centralized the data.

The authors utilized Stata12.0 which was one of the most popular and easiest econometrics empirical software to perform panel data regression. And it was widely used in dynamic panel data analysis. The regression model was shown as Formula (1):

$$
A d v-\alpha_{1} \operatorname{Product}(-1)+\alpha_{2} \operatorname{Cost}(-1)+\alpha_{3} \text { Reputation }(-1)+\varepsilon
$$

\section{RESULTS AND DISCUSSION}

\section{Impacts of Different Platforms}

From the results shown in Table 1, in terms of product optimization strategy, whether import retail e-commerce sellers allowed consumers to return commodities was directly proportional to the competitive advantage of sellers. But it was not significant on the model 3, which indicated that most of the consumers on Jingdong Global Purchase were not very concerned about the whether commodities could be returned. It seemed that consumers were satisfied with the quality of commodities bought 
Table 1. Different platforms regression results of factors affecting the competitive advantage of import retail e-commerce sellers

\begin{tabular}{|c|c|c|c|c|c|c|}
\hline Variables & \multicolumn{2}{|c|}{$\begin{array}{l}\text { Model 1: The Competitive } \\
\text { Advantage of All Sellers } \\
\text { On } 3 \text { Categories of } \\
\text { Commodities }\end{array}$} & \multicolumn{2}{|c|}{$\begin{array}{c}\text { Model 2: The Competitive } \\
\text { Advantage of Sellers On } 3 \\
\text { Categories of Commodities On } \\
\text { Tmall International }\end{array}$} & \multicolumn{2}{|c|}{$\begin{array}{l}\text { Model 3: The Competitive } \\
\text { Advantage of Sellers On } 3 \\
\text { Categories of Commodities On } \\
\text { Jingdong Global Purchase }\end{array}$} \\
\hline Return(-1) & $\begin{array}{l}227.43^{*} \\
(2.06)\end{array}$ & $\begin{array}{l}246.21^{*} \\
(1.79)\end{array}$ & $\begin{array}{l}216.09 * * \\
(2.37)\end{array}$ & $\begin{array}{l}229.08^{*} \\
(2.00)\end{array}$ & $\begin{array}{l}226.81 \\
(0.12)\end{array}$ & $\begin{array}{l}281.99 * \\
(1.91)\end{array}$ \\
\hline $\operatorname{ETA}(-1)$ & $\begin{array}{l}-186.92 * * * \\
(-8.95)\end{array}$ & $\begin{array}{l}-197.11 * * \\
(-2.36)\end{array}$ & $\begin{array}{l}-199.12 * * * \\
(-9.53)\end{array}$ & $\begin{array}{l}-221.98^{*} \\
(1.82)\end{array}$ & $\begin{array}{l}-205.47 * * * \\
(-6.35)\end{array}$ & $\begin{array}{l}-319.20 * * * \\
(-5.81)\end{array}$ \\
\hline Freight(-1) & $\begin{array}{l}448.67 * * * \\
(18.52)\end{array}$ & $\begin{array}{l}209.21 * * * \\
(15.67)\end{array}$ & $\begin{array}{l}512.96 \\
(0.19)\end{array}$ & $\begin{array}{l}293.47 * \\
(1.91)\end{array}$ & $\begin{array}{l}498.87 * \\
(1.84)\end{array}$ & $\begin{array}{l}192.37 * \\
(1.89)\end{array}$ \\
\hline Price(-1) & $\begin{array}{l}-1.21 * * \\
(-2.50)\end{array}$ & $\begin{array}{l}-7.47 * * \\
(-3.59)\end{array}$ & $\begin{array}{l}-2.17 * * \\
(-2.16)\end{array}$ & $\begin{array}{l}-6.69 * * * \\
(-4.24)\end{array}$ & $\begin{array}{l}-3.14 * * * \\
(3.31)\end{array}$ & $\begin{array}{l}-8.24^{*} \\
(1.83)\end{array}$ \\
\hline Reply(-1) & $\begin{array}{l}19.23 * * \\
(2.45)\end{array}$ & $\begin{array}{l}29.72 * * * \\
(3.26)\end{array}$ & $\begin{array}{l}21.99 * \\
(1.99)\end{array}$ & $\begin{array}{l}24.17 * \\
(2.02)\end{array}$ & $\begin{array}{l}26.71 \\
(1.23)\end{array}$ & $\begin{array}{l}28.08^{*} \\
(1.76)\end{array}$ \\
\hline$N R(-1)$ & & $\begin{array}{l}-179.33^{* * *} \\
(-4.26)\end{array}$ & & $\begin{array}{l}-210.17^{*} \\
(-1.99)\end{array}$ & & $\begin{array}{l}-188.03 \\
(-0.20)\end{array}$ \\
\hline $\begin{array}{l}\text { Price(- } \\
1)^{*} N R(-1)\end{array}$ & & $\begin{array}{l}-38.24 * \\
(-2.19)\end{array}$ & & $\begin{array}{l}-29.74 * * \\
(-2.40)\end{array}$ & & $\begin{array}{l}-57.80 \\
(-1.01) \\
\end{array}$ \\
\hline Speed(-1) & $\begin{array}{l}434.06^{* * * *} \\
(9.21)\end{array}$ & $\begin{array}{l}378.62 * * * \\
(8.19)\end{array}$ & $\begin{array}{l}472.06^{* * * *} \\
(8.77)\end{array}$ & $\begin{array}{l}231.48 * * \\
(2.21)\end{array}$ & $\begin{array}{l}388.31 * * * \\
(15.01)\end{array}$ & $\begin{array}{l}249.88 * * \\
(2.98)\end{array}$ \\
\hline$C$ & $\begin{array}{l}-275.92 \\
(-15.12)\end{array}$ & $\begin{array}{l}-672.06 \\
(-17.15)\end{array}$ & $\begin{array}{l}-305.92 \\
(-17.28)\end{array}$ & $\begin{array}{l}-771.87 \\
(-23.93)\end{array}$ & $\begin{array}{l}-289.25 \\
(-27.91)\end{array}$ & $\begin{array}{l}-851.63 \\
(-38.93)\end{array}$ \\
\hline Number & \multicolumn{2}{|l|}{18144} & \multicolumn{2}{|l|}{9072} & \multicolumn{2}{|l|}{9072} \\
\hline$R^{2}$ & 0.622 & 0.591 & 0.601 & 0.541 & 0.626 & 0.515 \\
\hline
\end{tabular}

from Jingdong Global Purchase, and descriptions of the products by sellers were consistent with commodities enough that consumers could buy well-content commodities. In terms of cost leadership strategy, consumers could low their purchasing cost by the reduction of intermediate links with the popularity of e-commerce, results showed Hypothesis Five was proved. The effectiveness of whether sellers exempt postage for consumers was verified by most models except model 2 , which showed that these consumers were not so concerned about postage. In terms of reputation priority strategy, the positive effect of sellers' rating provided by consumers to sellers' competitive advantage was obvious. The total volume of replies was positively proportional to the competitive advantage of import retail e-commerce sellers obviously, which indicated that it was essential to management online reviews by sellers. Replies to questions posed by consumers timely would be rationally to enhance sellers' competitive advantage. Furthermore, the negative comments' ratio on Tmall International has a stronger negative effect than which on Jingdong Global Purchase.

In addition, the seller's negative rating rate would enhance the negative effect of the price on the competitive advantage. In other words, good reputation to sellers could weaken the negative effect of price of the product to the competitive advantage. Due to the fierce competition among import retail e-commerce sellers, the price variance was not too great. For example, the mean value was 106.79 and the standard deviation was 14.73 for 28 Kao diapers' sellers ${ }^{23}$ through the descriptive statistics in this paper. Therefore, consumers would pay much more attention to online word of mouth under similar conditions of price, which verified Hypothesis Eight. Positive online word of mouth will weaken the disadvantage of price for sellers. The negative effect of the negative comments' ratio to the sellers' competitive advantage based on samples from Tmall International was higher than samples from 
Jingdong Global Purchase. It indicated that reputation priority strategy played a stronger role on the third-party residing type Platforms, which confirmed our Hypothesis Ten-3.

\section{Impacts of Different Commodities}

The authors have made three models above in order to do regression to three categories of commodities, compare the difference of the competitive advantage among three categories of commodities. In terms of product optimization strategy, results showed import retail e-commerce sellers allowed consumers to return commodities would enhance most sellers' competitive advantages. But it was not so obviously on mother and infant supplies. The quality requirement was very high for mother and infant supplies such as milk powder. Goods were not allowed to be returned after sold. However, sellers should prepare commodities could be returned for cosmetics, because this group of consumers was so captious, whether import retail e-commerce sellers allowed consumers to return commodities was obviously directly proportional to the competitive advantage of sellers, which was consistent with our analysis above and Hypothesis One. Moreover, the authors found that price of mother and infant supplies were directly proportional to the competitive advantage of sellers. It illustrated that this group of consumers were willing to spend more money for children to ensure the quality of the goods. The authors could easily see that expected arriving days of mother and infant supplies had a stronger negative effect to the competitive advantage of import retail e-commerce sellers than other two categories of commodities. Because most of mother and infant supplies the authors selected as samples in this paper were milk power with a short expiration period. Consumers would have a high demand for the expected arriving day as the sooner consumers received, the fresher it kept. The authors found that the competitive advantage of cosmetics sellers would not be enhanced with the shortened expected arriving days, because of the following two reasons. Firstly, as cosmetics always have a longer expiration period than other categories of commodities, so consumers would not care so much about the arriving date. Secondly, this party of domestic customers was so captious with commodities and they could not confirm the quality of commodities before receiving. They simply thought that the longer the expected arriving days was, the more likely it was direct mail from aboard and the higher quality it has. In terms of cost leadership strategy, whether sellers exempt postage for consumers was verified, this verified Hypothesis Three. The price of commodities has negative effect to the competitive advantage of import retail e-commerce sellers, but it was not obvious on Model 4 (see Table 2) and Model 6. As milk powder and health care products belonged to searching goods, most of consumers bought them online after recommendations of friends. Consumers had certain tendentiousness for commodities before order online, so they would not look for, compare and select them as carefully as experience products. In terms of reputation priority strategy, it seemed that consumers were not so care about the rating to the speed of the delivery on health care products as these groups of consumers care less about seller's delivery speed as they had a longer expiration period. The total volume of replies was positively proportional to the competitive advantage of import retail e-commerce sellers obviously, which has a consistent conclusion with above analysis with different e-commerce platform.

In addition, the negative comments' ratio would enhance the negative effect of the price of commodities to the competitive advantage after the authors took interaction term into models, which verified assumption Hypothesis Eight. Consumers on mother and infant supplies and health care products care more about online reputation than price. But the Model 5 showed that the price of commodities was inversely proportional to the competitive advantage of import retail e-commerce sellers, because this group of consumers was mostly young women who care more about price more than other customers groups, and they also care about the rating to the speed of the delivery, the consistence of the description to the product and the service of the seller. Moreover, it can be observed that the reputation priority strategy has a stronger effect on the sellers' competitive advantage in mother and infant supplies than the other two categories of commodities, and the negative comments' 
Table 2. Different commodities regression results of factors affecting the competitive advantage of import retail e-commerce sellers

\begin{tabular}{|c|c|c|c|c|c|c|}
\hline Variables & \multicolumn{2}{|c|}{$\begin{array}{l}\text { Model 4: The Competitive } \\
\text { Advantage of All Sellers On } \\
\text { Mother and Infant Supplies }\end{array}$} & \multicolumn{2}{|c|}{$\begin{array}{l}\text { Model 5: The } \\
\text { Competitive Advantage of } \\
\text { All Sellers On Cosmetics }\end{array}$} & \multicolumn{2}{|c|}{$\begin{array}{l}\text { Model 6: The Competitive } \\
\text { Advantage of All Sellers On } \\
\text { Health Care Products }\end{array}$} \\
\hline Return(-1) & $\begin{array}{l}199.43 \\
(1.76)\end{array}$ & $\begin{array}{l}215.61 * \\
(2.10)\end{array}$ & $\begin{array}{l}186.20 \text { *** } \\
(2.97)\end{array}$ & $\begin{array}{l}213.80 * * \\
(2.23)\end{array}$ & $\begin{array}{l}215.17 * \\
(1.92)\end{array}$ & $\begin{array}{l}231.11 * * \\
(2.20)\end{array}$ \\
\hline $\operatorname{ETA}(-1)$ & $\begin{array}{l}-291.66 * * * \\
(-17.71)\end{array}$ & $\begin{array}{l}-323.24 * * \\
(-18.83)\end{array}$ & $\begin{array}{l}-196.61 \\
(-1.58)\end{array}$ & $\begin{array}{l}-217.22 * * \\
(-2.30)\end{array}$ & $\begin{array}{l}-185.89 \\
(-1.35)\end{array}$ & $\begin{array}{l}-203.00^{*} \\
(-1.81)\end{array}$ \\
\hline Freight(-1) & $\begin{array}{l}368.10 * * \\
(2.09)\end{array}$ & $\begin{array}{l}319.84 * * * \\
(6.87)\end{array}$ & $\begin{array}{l}423.81 * * \\
(2.22)\end{array}$ & $\begin{array}{l}493.47 * \\
(1.80)\end{array}$ & $\begin{array}{l}187.53 * * \\
(2.73)\end{array}$ & $\begin{array}{l}197.36 * * \\
(2.78)\end{array}$ \\
\hline Price(-1) & $\begin{array}{l}2.20 \\
(0.61)\end{array}$ & $\begin{array}{l}-5.73^{*} \\
(-1.99)\end{array}$ & $\begin{array}{l}-3.17 * * * \\
(-4.72)\end{array}$ & $\begin{array}{l}-4.23 * * * \\
(-5.42)\end{array}$ & $\begin{array}{l}-4.44 \\
(0.70)\end{array}$ & $\begin{array}{l}-5.18^{*} \\
(1.90)\end{array}$ \\
\hline Reply(-1) & $\begin{array}{l}21.93 * * \\
(2.37)\end{array}$ & $\begin{array}{l}49.72 * * * \\
(13.26)\end{array}$ & $\begin{array}{l}34.82 * * \\
(2.91)\end{array}$ & $\begin{array}{l}44.36^{* * *} \\
(2.61)\end{array}$ & $\begin{array}{l}36.71 * * * \\
(21.46)\end{array}$ & $\begin{array}{l}53.01 * * * \\
(11.38)\end{array}$ \\
\hline$N R(-1)$ & & $\begin{array}{l}-325.03 * * * \\
(-3.67)\end{array}$ & & $\begin{array}{l}-288.34^{* *} \\
(-2.37)\end{array}$ & & $\begin{array}{l}-331.97 * \\
(-1.99)\end{array}$ \\
\hline Price $(-1)^{*} N R(-1)$ & & $\begin{array}{l}-46.86^{* * * *} \\
(-3.71)\end{array}$ & & $\begin{array}{l}-38.23^{* *} \\
(-2.91)\end{array}$ & & $\begin{array}{l}-31.22 * \\
(-1.90)\end{array}$ \\
\hline Speed (-1) & $\begin{array}{l}395.39 * * \\
(2.11)\end{array}$ & $\begin{array}{l}382.20 * * * \\
(2.91)\end{array}$ & $\begin{array}{l}272.44^{*} \\
(1.87)\end{array}$ & $\begin{array}{l}222.29 * \\
(1.90)\end{array}$ & $\begin{array}{l}311.24 \\
(1.14)\end{array}$ & $\begin{array}{l}451.80 * * * \\
(4.48)\end{array}$ \\
\hline$C$ & $\begin{array}{l}-173.63 \\
(-13.41)\end{array}$ & $\begin{array}{l}-596.82 \\
(-15.11)\end{array}$ & $\begin{array}{l}-383.08 \\
(-18.99)\end{array}$ & $\begin{array}{l}-564.19 \\
(-19.34)\end{array}$ & $\begin{array}{l}-257.84 \\
(-19.00)\end{array}$ & $\begin{array}{l}-588.03 \\
(-19.52)\end{array}$ \\
\hline Number & \multicolumn{2}{|l|}{18144} & \multicolumn{2}{|l|}{9072} & \multicolumn{2}{|l|}{9072} \\
\hline$R^{2}$ & 0.609 & 0.523 & 0.690 & 0.558 & 0.694 & 0.589 \\
\hline
\end{tabular}

ratio also has a significantly higher negative effect on the price in mother and infant supplies than the other two categories. The results confirmed our Hypothesis Ten-2.

\section{Robustness Test}

In order to verify whether the results of the above models were robust and reliable, the authors used the rating to consistence of the description to the product instead of the rating to seller's delivery speed, used logistics ways by sellers ${ }^{24}$ instead of the expected arriving days to do robustness test. Results showed that it was obvious for the effect that the rating to consistence of the description to the product to sellers' competitive advantage, and the regression coefficient of it on mother and infant supplies was the maximum, which proved that mother and infant supplies played a stronger role in reputation priority strategy. The t-value of logistics ways was obvious and the symbol of coefficient was in contrast with which on expected arriving days. It illustrated that the logistics ways by import retail e-commerce sellers was directly proportional to the competitive advantage of sellers. The Hypothesis Four and above analysis results were verified.

\section{CONCLUSION AND INSPIRATION}

\section{Conclusion}

To be specific, firstly, import retail e-commerce sellers could shorten the expected arriving days to attract customers' attention, especially in mother and infant supplies. But this was not applied to all categories of commodities. So the authors suggested import retail e-commerce sellers could shorten the expected arriving days of mother and infant supplies, but not to cosmetics. Secondly, as mother 
and infant supplies and health care products were searching products, which meant that customers would not spend much time on comparing and selecting them. They would not want to buy searching products which were returned. The authors suggested import retail e-commerce sellers on mother and infant supplies and health care products should take the promotion method of sales return very carefully. Thirdly, as the authors mentioned above, import retail e-commerce sellers could invest warehouse in bonded area to enhance their advantage of logistics ways. Because it could shorten the delivery period in order to reduce the waiting costs of customers, and promote the shopping experience. The mode was well estimated in the first " $5+2$ " 25 cross-border e-commerce pilot cities ( $\mathrm{Li}$ $\& \mathrm{Ma}, 2016)$. The authors could conclude that sellers investing in building warehouse in bonded area could enhance the competitive advantage of import retail e-commerce sellers. Fourthly, import retail e-commerce sellers could directly cooperate with branding parties in order to reduce the purchasing cost. Especially for the commodities that consumers care more about the price such as cosmetics. But low price promotion was not suitable for all categories of commodities, such as mother and infant supplies, consumers of this commodity would care more about the quality than the price. So other customers' online reputation would be so important. The authors suggested import retail e-commerce sellers could directly cooperated with branding parties in order to reduce the purchasing cost, do not take low price promotion on mother and infant supplies. Fifthly, import retail e-commerce sellers should raise their online reputation undoubtedly. Specific measures include manage the quality of the goods, ensure the rate of certified products, promote service level and speed of delivery. As other customers' online reviews could promote he competitive advantage of sellers (Zhang \& Vásquez, 2014; Qian, Cao and Li, 2011). So sellers could send gifts to consumers who provide good online reviews in order to encourage buyers to show high praise and share experiences. As replies to online reviews have positive effect on competitive advantages (Francis \& Buttle 1998), import retail e-commerce sellers should treat online reviews carefully. To be specific, they should try best to answer all the questions customers issued online in time. Finally, the third-party residing platforms have a stronger effect on reputation priority strategy than that on comprehensive platforms. But the authors should do more detailed work in analyzing the factors such as residing fee and service of the platform to know which kind of platforms has more advantageous for sellers.

\section{Inspiration}

Firstly, our samples were taken from Tmall International and Jingdong Global Purchase, the biggest two e-commerce platforms in China with the total sales volume exceed half of the whole sales in 2016. But it was difficult to rule out the influence of the inherent characteristics of platform sellers and consumers, so conclusions of this paper would be validated in a wider range in future. Secondly, the authors selected the vast majority of sellers who sell the top 3 categories of commodities, due to the fact the development of import retail e-commerce in China has been just started, and many public data has not yet been fully formed. The samples available for scholars to analyze would be more abundant with the development of the industry. Scholars could do more detailed analysis such as classify consumers' consumption custom. Thirdly, what kind of platform was suitable for import retail e-commerce sellers to reside needed to be researched by analyzing the factors such as residing fee and service of the platform. All these issues can be considered in future studies. 


\section{REFERENCES}

AliResearch consulting company. (2016). The future of the trade: cross-border electricity connecting to world. Arndt, J. (1967). Role of Product-related Conversations in the Diffusion of a New Product. JMR, Journal of Marketing Research, 1(1), 291-295. doi:10.2307/3149462

Chen, M. C., Hsu, C. L., Chang, K. C., \& Chou, M.-C. (2015). Applying Kansei engineering to design logistics services-A case of home delivery service. International Journal of Industrial Ergonomics, 1(48), 46-59. doi:10.1016/j.ergon.2015.03.009

Cheung, M., Luo, C., Sia, C., \& Chen, H. (2009). Credibility of electronic word-of-mouth: informational and normative determinants of on-line consumer recommendations. International Journal of Electronic Commerce, 13(4), 9-38. doi:10.2753/JEC1086-4415130402

Francis, A. (1998). Word of mouth: Understanding and managing referral marketing. Journal of Strategic Marketing, 6(3), 241-254. doi:10.1080/096525498346658

Ge, H., \& Zhang, Y. (2013). A Method of the Benchmarks Selection Based on the Choice Preference of Competitive Strategies. Chinese Journal of Management, 7, 972-978.

Guo, Y., Wang, K., \& Chen, G. (2015). Research on traditional retail's transformation and upgrading based on online and offline integration. Chinese Journal of Management, 1, 726-731.

Herrera, E. (2014). The drivers and impediments for cross-border e-commerce in the EU. Information Economics and Policy, 1(28), 83-96. doi:10.1016/j.infoecopol.2014.05.002

Hsiao, Y. H., Chen, M. C., \& Liao, W. C. (2017). Logistics service design for cross-border E-commerce using Kansei engineering with text-mining-based online content analysis. Telematics and Informatics, 4(4), 284-302. doi:10.1016/j.tele.2016.08.002

iResearch consulting company. (2017). China's cross-border online user research report in 2016.

Pengbo Li, Feng Ma. (2016). The revelation of import retail e-commerce. Publishing house of electronics industry.

Li, W., Wu, D., \& Xu, H. (2007). Reputation in China's Online Auction Market: Evidence from the Taobao Website. Nankai Business Review, 10(5), 36-46.

Liu, J. (2015). On customs control over b2c trade in inward e-commerce. Journal of Customs and Trade, 36(1), $58-71$.

Liu, J., Liu, W., Liu, X., \& Zhao, J. (2015). Research of sino-russian cross-border e-commerce development based on grounded theory method. China Soft Science, 9, 27-40.

Liu, W., \& Xu, P. (2014). A study on influencing factors of the helpfulness of online reviews in o2o of restaurant industry—based on Tobit Model. Chinese Journal of Management Science, 5(24), 168-176.

Lu, X., \& Feng, Y. (2009). The value of Internet word of mouth - based on the research on online restaurant reviews. Management World, 7, 126-132.

Mao, Z., \& Yang, L. (2017). Supply-side reform and the residents' consumption structure upgrade under the economic globalization background. Finance \& Economics, 1, 72-82.

Mudambi, S. M., \& Schuff, D. (2010). What makes a helpful online review? A study of customer review on Amazon. Management Information Systems Quarterly, 34(1), 185-200. doi:10.2307/20721420

National Bureau of Statistics of China. (2017). 2016 China Statistical Yearbook. China Statistical Publishing House.

Porter, M. E. (2001). Strategy and the internet. Harvard Business Review, 3, 63-78. PMID:11246925

Qian, X., Cao, T., \& Li, W. (2011). Promotion Pressure, Officials' Tenure and Lending Behavior of the City Commercial Banks. Economic Research Journal, 12, 72-85.

Rodder, W., \& Reucher, E. (2012). Advanced X-efficiencies for CCR- and BCC-models - towards Peer-based DEA controlling. European Journal of Operational Research, 219(2), 467-476. doi:10.1016/j.ejor.2011.12.024 
Saipe, A. (2013). The impact of logistics services on E-commerce in Canada. Industry Canada. Management Science, 3, 77-86.

Sohail, S. S., \& Ali Siddiqui, J. R. (2016). Feature extraction and analysis of online reviews for the recommendation of books using opinion mining technique. Perspectives on Science, 1(8), 754-756. doi:10.1016/j.pisc.2016.06.079

Sparks, B. A., So, K. K. F., \& Bradley, G. L. (2016). Responding to negative online reviews: The effects of hotel responses on customer inferences of trust and concern. Tourism Management, 23(53), 74-85. doi:10.1016/j. tourman.2015.09.011

Sun, P., Zhang, J., \& Jiang, X. (2017). E-Commerce, searching cost and consumer price change: evidence from the micro retailing market. Economic Research Journal, 7, 12-23.

Vinodhini, G., \& Chandrasekaran, R. M. (2016). A comparative performance evaluation of neural network based approach for sentiment classification of online reviews. Journal of King Saud University-Computer and Information Sciences, 28(1), 2-12. doi:10.1016/j.jksuci.2014.03.024

Wang, H., Wang, J., \& He, Y. (2007). Brand name, country of origin, price for perceived quality and purchase intention: The implied effect. Nankai Management Review, 6, 39-51.

Wang, J., \& Du, J. (2016). Exploring the Cross-Border E-Commerce Development Model in the Belt and Road Economic Regions. China Business and Market, 30(9), 100-107.

Wu, D. (2007). Private order in online trade: Community, Reputation and Third-party Intermediaries. China Economic Quarterly, 3, 859-884.

Xue, Y., \& Guo, Y. (2012). Competitive Strategy of E-Business Sellers on Consumer-to-Consumer Platform: Based on Data from Taobao.com. Nankai Business Review, 9(5), 129-140.

Yan, Q., \& Meng, Y. (2013). Factors Affecting the Perceived Usefulness of Online Reviews-An Empirical Study Based on Online Film Reviews. Chinese Journal of Management Science, 21(1), 126-131.

Zhai, C., \& Li, Y. (2011). Study on Online Retailer's Return Policy in B2C Mode. Journal of Industrial Engineering and Engineering Management, 25(1), 62-68.

Zhang, Y., \& Vásquez, C. (2014). Hotel' responses to online reviews: Managing consumer dissatisfaction. Discourse. Context \& Media, 1(6), 54-64. doi:10.1016/j.dcm.2014.08.004

Zhao, J., Qiu, J., Hu, X., \& Liu, Y. (2017). Based on differentiated product launches from strategic consumers and Pricing research. System Engineering Theory and Practice, 37, 99-108.

Zheng, C.,, Wang, Q.,, \& Liu, W., Ni, L.L. \& Wu, Y. (2014). Influences of Characteristics of E-Business Market on Product Innovation: An Empirical Study. Journal of Management Sciences, 6, 90-102.

\section{ENDNOTES}

1 Imported retail e-commerce refers to business activities that domestic consumers complete the transaction by concluding the transaction, carrying on the payment and settlement, delivering goods by cross-border logistics servicers.

2 Specific tax rates could be seen in http://www.customs.gov.cn/publish/portal0/.

3 CBLS means Cross-Border Logistics Service which provided services including customs clearance, logistics and value-added services.

$4 \quad$ Positive list means import retail sellers can only sell commodities on the list.

5 Now there were two ways for import retail e-commerce sellers to deliver goods cross border. Firstly, direct mail import which means sellers aboard send commodities to domestic consumers directly by parcel post. Secondly, bonded import which means sellers stock up goods in warehouse in bonded area in bulk, delivery commodities to consumers scattered after consumers ordered online.

6 Panel data means taking multiple section based on time series and taking observation of sample data on the cross section at the same time.

7 This survey concluded 450 questionnaires, included Chongqing and Hangzhou 100 respectively, another 5 cities 50 respectively. The authors took back 291 questionnaires, with the recovery rate of $64.67 \% .253$ 
effective answers which were $86.94 \%$ to the total questionnaires, include 67 in Chongqing, 61 in Hangzhou, 36 in Shanghai, 27 in Shenzhen, 22 in Guangzhou, 21 in Zhengzhou and 19 in Ningbo. The authors did not display the questionnaire and results because of the limited space, readers who were interested can ask the author for it. This means seven cities which wre Hangzhou, Chongqing, Shanghai, Ningbo, Zhengzhou, Guangzhou and Shenzhen could carry out bonded import mode.

The third-party residing type platforms refer to platforms would not participate in the transaction while only promote the transaction by provide information of buyers and sellers. Self-operated platforms refer to platforms utilize the high credit itself to attract consumers and participate into the transaction. Comprehensive e-commerce platforms refer to a combination of the above two modes of e-commerce platforms.

The authors considered competition among import retail e-commerce sellers, did not consider self-operated platforms, so Netease Kaola was not taken as sample.

1124 products refer to Aptamil milk power from German, Nutrilon milk power from Netherlands, Abbott milk power from US, Aptamil milk power from Australia, NUK feeder from German, Pigeon feeder from Japan, Merries paper diaper from Japan, GOO.N paper diaper from Japan, Jayjun facial mask from Korea, Sulwhasoo facial mask from Korea, SNP facial mask from Korea, LOREAL Men's facial cleanser from French, LOREAL shampoo from French, Mentholatum Men's facial cleanser from Japan, Shiseido shampoo from Japan, Schwarzkopf shampoo from Japan, Swisse vitamin from Australia, Blackmores vitamin from Australia, Centrum vitamin from New Zealand, GNC fish oil from US, Swisse fish oil from Australia, Amway albumen powder from US, HERBALIFE albumen powder from US, BPI albumen powder from US.

The process included commodities cross border, refund, eliminate customs records, tax rebates and other processes. 1 stood for import retail sellers allowed consumers to return commodities, 0 stood for not. There were direct or indirect correlations between two kinds of strategies. For example, the expected arriving days(ETA) and the logistics ways by import retail e-commerce sellers(Way), later the authors would calculate in the correlation test, and considered it in the actual return. 1 stood for sellers exempt postage for consumers, 0 stood for not.

1 stood for bonded imported way, 0 stood for direct mail way.

The authors did not display the result because of the limited space, readers who were interested can ask the author for it.

The ratio that the number of negative words to the total words. the author for it. The authors did not display the result because of the limited space, readers who were interested can ask the author for it.

The authors did not display the result because of the limited space, readers who were interested can ask the author for it. The correlation coefficient was -0.89 , as the expected arriving days of direct mail was always longer than the expected arriving days of bonded import and there was a negative relationship between the expected arriving days and the logistics ways. The authors did not display all the descriptive statistics of variables for all commodities because of the limited space, readers who were interested can ask the author for it. 1 stood for bonded imported way, 0 stood for direct mail way.

25 The first " $5+2$ " cross-border e-commerce pilot cities were Hangzhou, Chongqing, Ningbo, Shanghai, Zhengzhou, Guangzhou, Shenzhen.

Xuanxuan Zhang is a doctoral candidate in Chongqing University with a major in applied economics, research direction is electronic commerce, business management. Zhang has the master's degree in University of Electronic Science and Technology of China, the major for master's degree was Financial Engineering. Zhang has a bachelor's degree in Chongqing University, the major for bachelor's Degree was Mathematics and Applied Mathematics. Zhang has certain thoughts and insights in the field of cross-border e-commerce in China. Zhang has published some papers in some domestic journals with certain significance, such as "Stocking and Pricing Strategy of Import Cross Border E-Commerce Based on Bertrand Model" and "Analysis on Competition Strategy of B2C Import Cross-Border E-Commerce Seller: As an Example of www tmall hk". 